\title{
23. Comparative Perspectives on Basin Governance in the Murray- Darling Basin: Insights from the western United States
}

\author{
Dustin Garrick, Rosalind Bark
}

\section{Introduction}

The Murray-Darling Basin (MDB) is internationally recognised for innovation in basin governance to achieve more sustainable outcomes. This chapter examines water-management experiences from the western United States relevant to the emerging public dialogue about the Murray-Darling Basin Plan. We argue that a comparative perspective offers more scope for exchanging policy and practical lessons than previously recognised. Australia imparts more lessons than it stands to learn from the exchange, but the western United States has both success stories and failures that are instructive in four elements of sustainable water reforms, including: a) balancing multiple objectives in water reform; b) defining environmental-flow requirements; c) basin planning across jurisdictions; and d) adaptive learning in environmental-water recovery. The Columbia and Colorado river basins bracket the diverse range of management challenges and institutional innovations in the western United States. Both have engaged with diverse stakeholders to reconcile multiple objectives in long-range planning, particularly with indigenous communities. The Colorado River has responded to water-supply variability by building technical capacity for engagement in State and tribal stakeholder groups. The Columbia has pioneered adaptive learning in market-based environmental-water recovery through nested governance arrangements that combine bottom-up planning and implementation with basinwide financing and accountability. This preliminary comparison highlights the broad scope for mutual learning and the need for sustained and systematic cross-case comparisons to realise this potential.

Australia's experiences with integrated basin governance are the envy of much of the world and have attracted increasing interest about lessons learned (Pilz 2010). The development of the Murray-Darling Basin Plan is the most recent milestone in 'Australia's internationally recognized record of water reform' (Langford et al. 2010). The Basin Plan aims to fulfil the mandate of the Commonwealth Water Act 2007 to establish environmental-water requirements 
and sustainable diversions limits (SDLs) that optimise economic, social and ecological outcomes of water use. The public reception of the Plan-particularly in regional Australia - underscores the enduring implementation challenges of a whole-of-basin approach.

Intensified competition for water and concern about future trends in hydroclimatology have forced other countries to join Australia in responding to water scarcity. The western United States is uniquely positioned to offer experience relevant during the ongoing public dialogue about the Basin Plan. It shares many of the Murray-Darling Basin's defining challenges - aridity, highly variable stream flow, over-allocation and coordination challenges across irrigation districts, States and the Federal Government - and the western United States has both success stories and failures that are instructive.

James Wescoat jr (2005), North American Water Resource Geographer, summarised his observations from decades of experience comparing waterpolicy lessons in the western United States and internationally: 'I found much in common between water management in the western United States and other parts of the world, and I became convinced that geographic comparison of water policy lessons has practical as well as intellectual value.' We follow James Wescoat jr (2005) in recognising the practical and intellectual value of these cross-case comparisons. It is, however, important to note that several conceptual and methodological frameworks exist to structure comparison and accumulate learning; here, our goal is to describe the scope for comparison to motivate more systematic comparisons in future work.

In this chapter, we examine four dimensions of the public dialogue about the Basin Plan: a) balancing multiple objectives in water reform; b) defining environmental-water requirements; c) basin planning across jurisdictions; and d) adaptive learning in environmental-water recovery. We develop this contribution in four parts. In section two, we briefly review the evolving waterpolicy context in Australia to introduce key elements of the public dialogue about the Basin Plan. Section three presents the rationale for choosing the Colorado and Columbia basins as case studies of basin governance in the US west, and it describes their physical characteristics and water institutions. The fourth section compares the US basins along the focal dimensions summarised above. The fifth section summarises key lessons for the MDB in relation to the strengths and challenges associated with these four elements in the Basin Plan. We conclude by underscoring the scope for mutual learning and further comparative research. 


\section{Policy Evolution in Basin Planning}

The Basin Plan exists within a wider context of federal policy reforms to address competition for scarce and variable water supplies in the MDB. The recent history of reforms to achieve integrated basin governance begins with the 1992 MurrayDarling Basin Agreement and the 1994 Council of Australian Governments (COAG) framework (Connell and Grafton 2008). These reforms established a framework and set of principles adopted through an intergovernmental agreement by the States, including recognition of environmental uses as legitimate and the establishment of limits on extractive uses. The 2004 Intergovernmental Agreement on a National Water Initiative built on the COAG framework and furthered its emphasis on market-enabling reforms, a return to environmentally sustainable levels of extraction, risk assignment, and future adjustment processes for water users and communities. The Water Act 2007 aimed to optimise the economic, social and environmental outcomes of water use. The Water Act further stipulates the need to identify environmental-water requirements, establish SDLs to meet these requirements, and prepare a Basin Plan towards these ends.

The Guide to the proposed Basin Plan (MDBA 2010) was released on 8 October 2010. It includes six elements (MDBA 2010:36)

1. determining environmental-water requirements

2. assessing socioeconomic impacts

3. establishing SDLs

4. transition to the SDLs

5. implementing the Basin Plan

6. delivering outcomes.

Of these, the assessment of socioeconomic impacts, establishment of SDLs and design of transitional arrangements have attracted extensive community interest and political response. The Murray-Darling Basin Authority (MDBA) commissioned a series of socioeconomic studies in the lead-up to the development of the Basin Plan, and additional analysis is under way. Concerns about the social and economic costs of ecologically sustainable policy making are not unique to Australia or the MDB, however, and the western United States has confronted similar challenges in the context of drought and endangered species. 


\section{Governance in the Colorado and Columbia Basins}

The Colorado and Columbia river basins bracket the diverse range of physical and institutional characteristics prevalent in the western United States. Both, however, are interstate and transnational rivers experiencing an increasing federal role in basin governance to coordinate multiple States and wateruser associations to share the benefits, costs and risks of water-planning and allocation decisions.

\section{Colorado}

\section{Physical Characteristics}

The Colorado River Basin covers $629100 \mathrm{sq} \mathrm{km}$ - roughly one-twelfth of the continental United States. The river descends $3658 \mathrm{~m}$ along its $2334 \mathrm{~km}$ length, and discharges into the Gulf of California. The average natural flow in the gauged record (1906-2008) at Lee Ferry is 18500 gigalitres. This average obscures high stream-flow variability: the low and high flows (6930 GL and $31200 \mathrm{GL}$ ) were recorded in 1977 and 1984, respectively. Flow variability is buffered by the large storage to run-off ratio in the basin, which approximates 4:1. Much of the 67 300 GL reservoir capacity is in Lakes Powell and Mead. The Colorado supports 30 million people, varied ecosystems, irrigates 800000 ha of crops, generates hydroelectricity and provides recreation.

\section{Water Institutions}

The Colorado is managed by the Secretary of the Department of the Interior, who has designated the US Bureau of Reclamation as its lead agency. It is a multi-jurisdictional watershed: seven States and the United Mexican States (Mexico) share the river. In the United States, the basin was divided into two (largely in accordance with hydrology) in the Colorado River Compact of 1922. The Upper Division States (UDS) include Colorado, New Mexico, Utah and Wyoming and the Lower Division States (LDS) include Arizona, California and Nevada. Although the interests of each State within the UDS and LDS differ, they do tend to negotiate as a block. Mexico has a separate entitlement as per a 1944 treaty.

\section{Columbia}

\section{Physical Characteristics}

The Columbia River Basin (668 $000 \mathrm{sq} \mathrm{km}$ ) is comparable in size with the Colorado but not in volume (see Table 23.1). The river discharges into the Pacific 
Ocean west of Portland, Oregon, after descending $820 \mathrm{~m}$ over $2000 \mathrm{~km}$ from its headwaters in British Columbia, Canada. It has an average volume at the Dalles Dam of 234945 GL-an order of magnitude higher than the Colorado. Stream flow is characterised by spatial and seasonal variability. Chronic seasonal water deficits in the tributaries occur in late summer when peak agricultural use coincides with natural low flows. The Columbia supports a population of seven million, 2.8 million ha of irrigated agriculture, and a salmon fishery with high ecological, cultural and economic significance. A series of 31 dams generates hydroelectric power through the Federal Columbia River Power System (FCRPS).

\section{Water Institutions}

The Columbia is managed by a 'patchwork quilt' of laws, policies and jurisdictions, with allocation authority vested at the State level (Schoessler et al. 1997). The Columbia traverses parts of eight States in the United States, and Canada. The Columbia differs from the Colorado because it lacks a lead federal agency in water planning and an interstate compact to apportion water rights between the States. The FCRPS establishes a federal overlay in water management for power and conservation activities under the 1980 Federal Power Act. Further, a 1961 international treaty shares flood control and hydropower benefits between Canada and the United States. Tribes have substantial property rights, including 1855 Stevens Treaty rights to salmon harvests.

Table 23.1 Physical and institutional dimensions

\begin{tabular}{c|l|c|l|l|l}
\hline & \multicolumn{4}{|c}{ Dimensions } \\
\hline Basin & \multicolumn{2}{|c|}{ Physical } & \multicolumn{3}{c}{ Institutions } \\
\hline & $\begin{array}{l}\text { Annual } \\
\text { inflow }\end{array}$ & \multicolumn{1}{c|}{ Size } & Basin regime & \multicolumn{1}{c}{ Federal role } & \multicolumn{1}{c}{ Objectives } \\
\hline Colorado & $\begin{array}{l}18500 \\
\mathrm{GL}\end{array}$ & $\begin{array}{l}629100 \\
\text { sq km }\end{array}$ & $\begin{array}{l}\text { Interstate } \\
\text { compact }\end{array}$ & $\begin{array}{l}\text { US Bureau of } \\
\text { Reclamation }\end{array}$ & $\begin{array}{l}\text { Multidimensional } \\
\text { 'Law of the River' }\end{array}$ \\
\hline $\begin{array}{c}\text { Columbia } \\
\text { Durray- }\end{array}$ & $\begin{array}{l}234945 \\
\mathrm{GL}\end{array}$ & $\begin{array}{l}668000 \\
\text { sq km }\end{array}$ & $\begin{array}{l}\text { Northwest } \\
\text { Power Act }\end{array}$ & $\begin{array}{l}\text { Northwest Power } \\
\text { and Conservation } \\
\text { Council }\end{array}$ & $\begin{array}{l}\text { Multidimensional } \\
\text { 'patchwork quilt' }\end{array}$ \\
\hline GL & $\begin{array}{l}1061469 \\
\text { sq km }\end{array}$ & $\begin{array}{l}\text { Cwlth Water } \\
\text { Act }\end{array}$ & $\begin{array}{l}\text { Murray-Darling } \\
\text { Basin Authority }\end{array}$ & $\begin{array}{l}\text { 'Optimise economic, } \\
\text { social and ecological } \\
\text { water use' }\end{array}$ \\
\hline
\end{tabular}

\section{Four Elements of Sustainable Water Reforms}

The MDB Plan reflects a commitment to reconcile multiple objectives, comprehensively specify environmental-water requirements, integrate planning at the basin scale, and implement transitional arrangements to comply with the 
SDLs established through this process. Neither the Colorado nor the Columbia has established comparable commitments, although the Columbia has invested in substantial institutional innovations and infrastructure.

\section{Balancing Multiple Objectives of Water Reform}

\section{Colorado}

Water reform in the Colorado Basin has been patchy and piecemeal under a framework of laws, regulations, court cases and treaties collectively known as the 'Law of the River'. The first of these - the 1922 Colorado River Compact sought to 'provide for the equitable division' of the Colorado River. The Compact was negotiated during wet conditions relative to the long-term average inflows over the 100-year gauged stream-flow record. A large research effort in the early 1990s - the 'Severe and Sustained Drought Study' — - sought to better understand the risks to water-supply reliability using both gauged and treering-based stream-flow records and basin-wide hydrological models. Policy recommendations were not enacted largely as a result of political complacency following high stream flows in 1995 and 1997. In fact, as the current drought intensified, the efforts of the basin States and the Secretary of the Department of the Interior were focused on how to share surplus flows, as decided in the Interim Surplus Guidelines (USDOI 2001). The severe drought that began in 1999 provided the 'focusing event' (Pulwarty and Melis 2001) for the Interim Guidelines for Lower Basin Shortages and the Coordinated Operations for Lake Powell and Lake Mead (USDOI 2007) ${ }^{2}$ and later for the first whole-ofbasin approach, initiated in January 2010 with the Bureau of Reclamation's Colorado River Basin Water Supply \& Demand Study (hereafter, Colorado Basin Study). The track record of reconciling multiple objectives has been limited, but capacity has grown. The deliberate adaptive-management approach in the Colorado has provided the basin States with sufficient flexibility to modify system management to changing conditions; the Bureau of Reclamation has engaged with States and tribes to develop technical capacity and cultivate stakeholder participation in the planning efforts.

\section{Columbia}

Unlike the Colorado, the Columbia lacks an interstate water compact to govern water sharing across the States. State water codes establish the contemporary

\footnotetext{
1 For studies relating to this effort, see 'Coping with a severe and sustained drought on the Colorado River', Journal of the American Water Resources Association, Special Issue, vol. 31, no. 5 (1995).

2 The 2007 Interim Guidelines incorporate: delivery cuts to LDS based on trigger elevations in Lake Mead; rules for the joint operation of Lakes Powell and Mead over the full range of storage conditions; and an innovative conservation mechanism: Intentional Created Surplus (ICS). ICS is currently available only to LDS but it is the probable mechanism for delta recovery in Mexico.
} 
objectives of water reform to resolve imbalances among water uses for hydropower, consumptive purposes, and fish. For example, the Washington Water Resources Act of 1971 seeks to protect and use water for the greatest benefit of the people of the State, and it explicitly includes the water needs for fish habitat; it also prioritises local solutions to water-resource management.

The recovery of migratory salmon fisheries impacted by hydropower generation and surface-water diversions has provided a primary impetus for regional coordination. The Northwest Power Act of 1980 established the Northwest Power and Conservation Council (NPCC), which released its first fish and wildlife plan in 1982, with the most recent amendments in 2009. Recovery activities implement the fish and wildlife program strategy developed by the NPCC using more than \$8 billion from 1999-2009, financed and administered by the Bonneville Power Administration, a federal power utility with mitigation obligations (BPA 2010).

The Yakima River of the Columbia Basin includes one of the first three basin studies funded under the 2009 Secure Water Act; the Deschutes River Basin is another tributary of the Columbia that has received funding in the 2010 round of grants under the Act. The study scope is illustrative in contrast with the Colorado. The Yakima River Basin Study and Associated Basin Restoration Implementation Plan include a characterisation of current and future water needs (both in-stream and off-stream), an assessment of climate impacts, and an evaluation of alternatives for meeting in-stream and off-stream needs and integrating them with other restoration strategies. This study effort to rebalance human and environmental water uses at the basin scale comes closest to integrated management across multiple, competing objectives and stakeholder values.

\section{Defining Environmental Water Requirements}

\section{Colorado}

From the viewpoint of the Colorado River Basin, it is striking to read the explicit environmental-flow requirements for ecosystem function and specified ecosystem assets in the MDB Guide. It is not that there is an absence of environmental concern in the Colorado, ${ }^{3}$ but rather that system water is not explicitly set aside for environmental flows. The Colorado Basin Study will attempt to quantify

3 Prominent examples include the Glen Canyon Dam Adaptive Management Program, including experiments to restore sandbanks in the Grand Canyon National Park (see < http://pubs.usgs.gov/fs/2010/3009/fs20103009.pdf $>$ ) and ecosystem restoration efforts encompassed in the Lower Colorado River Multi-Species Conservation Plan. 
environmental-flow requirements for targeted areas. The location of the Colorado River delta in Mexico, however, means that water requirements for this ecosystem are outside the scope of the Basin Study. Neither the United States nor Mexico ensures minimum base flows or flood pulses to maintain the health of the delta ecosystem; the delta receives flows and sediments only during extreme flood events, such as in 1983. There are ongoing bi-national conversations on how to restore the delta; base flow requirements of $61.7 \mathrm{GL}$ with a flood pulse four or five times this volume every five years are often cited. ${ }^{4}$ The responsibility for securing these environmental flows would be shared equally between three partners: the United States, Mexico and a consortium of non-governmental organisations (NGOs). Such an agreement would provide a mechanism for Mexico and the NGOs to access storage in the United States.

\section{Columbia}

The Columbia River Basin has among the most advanced scientific knowledge and policy framework for meeting environmental needs in the western United States. Like the MDB, in the Columbia Basin, the recognition of environmental needs occurred after rivers had become oversubscribed. Methods for prescribing environmental flows first emerged in the western United States in the late 1940s (Tharme 2003), and efforts in the Columbia (Tennant 1976) were motivated by legal and regulatory salmon recovery efforts. Each State has adopted different methods for assessing and meeting environmental requirements based on minimum flows required for salmon migration. Oregon established the 1955 Minimum Perennial Streamflows program to preserve base flows. Washington established a similar program in the late 1960s, and Idaho and Montana followed suit in the 1970s.

A comprehensive framework for assessing and defining environmental needs has been elusive (NRC 2004); however, the listing of 13 salmon and steelhead runs under the Endangered Species Act in the early 1990s triggered more coordinated efforts to identify and mitigate factors constraining salmon recovery, including flow limitations. The 2000 and 2008 Biological Opinions on the FCRPS established flow-augmentation requirements on the main stem of the Columbia. Local and State processes have guided the development of flow requirements on the tributaries where salmon reproduce on small systems vulnerable to late-summer depletion during peak irrigation use. The lack of a comprehensive basin-wide assessment of environmental-flow needs in the Columbia akin to the effort being attempted in the MDB Plan has made it difficult to establish priorities and assess trade-offs among competing targets for water recovery.

4 These flow requirements were provided by personal communications with federal officials, but they are not yet 'official'. The authors are unsure whether these flow requirements are based on an assessment of ecosystem needs or political acceptability. 


\section{Basin Planning across Jurisdictions}

\section{Colorado}

The Colorado River Basin States are significant players with the Bureau of Reclamation in long-range planning, particularly with respect to proposed modifications to system management. Garrick et al. (2008) identified a key opportunity for stakeholder learning about the Reclamation Bureau's long-range planning model — specifically, the Colorado River Simulation System (CRSS) - in the almost sequential process of designing the 2001 Interim Surplus Guidelines (USDOI 2001) and the 2007 Interim Guidelines for Lower Basin Shortages and the Coordinated Operations for Lake Powell and Lake Mead (USDOI 2007). In the Environmental Impact Statement for the 2007 Interim Guidelines, the 'Basin States Alternative' was one of six reasonable operational alternatives analysed. The five alternatives (the sixth was the status quo) were developed collaboratively with NGOs, basin States, tribal and other stakeholders, in a process that depended on the transparency of CRSS and the ease and relative simplicity of the RiverWareTM software in which CRSS is implemented (Jerla et al. 2010). The 2007 Interim Guidelines will be up for renegotiation no later than 31 December 2020, at which time the Bureau of Reclamation, the basin States and other interested parties will evaluate the effectiveness of the new measures in increasing system management flexibility before extending them beyond 2026. Meanwhile, the Colorado Basin Study is the first authorised under the Secure Water Act; it builds on nearly a century of basin-scale conflict and coordination. A defining feature of this effort is federal coordination with the basin States, environmental NGOs and the tribes in assessing the long-range water supply and demand.

\section{Columbia}

In the absence of an interstate river compact, the NPCC and the federal agencies coordinating salmon recovery provide the primary opportunities for basinscale integration in long-range basin planning. The move towards catchmentscale governance and whole-of-basin integration, however, emerged from the bottom up at the local and State levels as an alternative to reliance on courts for conflict resolution in response to salmon declines (Benson 1996). The 2000 amendments to the NPCC Fish and Wildlife Program delineated 62 sub-basins and called for the development of fish and wildlife plans for the main stems of the Snake and Columbia river basins and 58 sub-basin plans to cover the tributaries. The sub-basin plans emphasised 'locally developed, integrated' plans to establish biological objectives and implementation strategies through a technical assessment, an inventory of past recovery efforts, and a management 
plan (NPCC 2005). The NPCC ensured basin-wide consistency with the Fish and Wildlife program by ratifying the sub-basin plans as part of the 2009 program amendments.

The sub-basin planning process dovetails with State-level programs to manage water resources along tributaries affected by groundwater pumping. In contrast with the statutory provisions establishing state-coordinated, local catchment planning in Oregon and Washington, catchments in Idaho and Montana have developed voluntary, bottom-up approaches to integrated planning. The Blackfoot Challenge of Western Montana is a noteworthy example, where a multistakeholder forum has coalesced since the early 1970s. The forum developed scientific, planning and drought-response measures, which culminated in voluntary diversion reductions to meet fisheries requirements established by State-held in-stream water rights that were historically unmet in dry years.

\section{Adaptive Learning in Environmental-Water Recovery}

\section{Colorado}

There are bi-national conversations on how to restore the Colorado delta, but for now, the environmental-flow requirements that have gained traction in the bi-national dialogue are for the Ciénega de Santa Clara, Mexico. The Ciénega is the largest wetland in the Sonoran Desert and an important rest stop along the Pacific Flyway; its restoration is also the unintended consequence of a temporary solution to a bi-national water-quality issue. In 1973 in response to unacceptably high salt loads, Minute 242 to the 1944 treaty was signed. In 1974 the US Congress passed the Colorado River Salinity Control Act, which authorised the Bureau of Reclamation to construct pipelines and the Yuma Desalting Plant (YDP). A bypass drain was constructed both as an interim measure to divert saline agricultural drainage outflow to the Santa Clara Slough and as the future conveyance of the YDP brine stream. Until 2009, US compliance with Minute 242 had been met by bypassing saline agricultural backflow to the Ciénega. Bypass water is not counted in Mexico's entitlement but rather is water in excess of LDS entitlements that is released from basin reservoirs.

In 2009, a decision was taken to both run the YDP at one-third capacity to conserve system flows and replace reduced bypass flows. The replacement bypass water has to be conserved or transferred within the system. The United States delivered its portion of these replaced flows (USDOI 2009:23); they represent the first dedicated environmental flows in the Lower Colorado River 
within the Colorado River Accounting System. This is a significant milestone and was not without its detractors; some argued that a better experiment would have been to monitor how the Ciénega responded to reduced flows and higher salt loads. Replacement flows are most likely to be met by contracting with an irrigation district to forbear a proportion of its irrigation entitlement, which is then transferred to one of the three responsible parties.

There are a number of long-term, large-volume and also pilot irrigation forbearance agreements in the US south-west that provide price points for such environmental transfers. The Bureau of Reclamation has engaged in five pilot projects to learn how best to design, monitor and implement these agreements and numerous lessons have been learned (Colby and Bark 2010). The 2004 pilot program was cancelled after Arizona raised objections to it. In the 2006-07 pilot program, the Bureau of Reclamation partnered with the Metropolitan Water District (MWD) of Southern California and the Palo Verde Irrigation District (PVID) Land Management Crop Rotation and Water Supply Program. This supplementary agreement with the Reclamation Bureau conserved 3.7 GL in 2006 and 8.6 GL in 2007. The 2008 and 2009 pilot programs were in Arizona and conserved $4.3 \mathrm{GL}$, while the 2010 program conserved 4.6 GL. Responding to lower agricultural prices, program costs fell from US $\$ 97$ 285/GL in 2008-09 to US\$72 964/GL in 2010. Longer-term agreements, such as the 35-year agreement signed in 2004 between MWD and PVID, transfer larger volumes - in this case, up to $160.4 \mathrm{GL} / \mathrm{yr}$. Irrigators are paid a combination of a sign-up payment and an exercise cost by MWD. The preferred solution is temporary transfers rather than permanent entitlement buy-outs.

\section{Columbia}

A number of market-based approaches to reallocate water for salmon recovery have been designed and tested in the Columbia Basin (Hardner and Gullison 2007). Enabling conditions have developed at the State level or within pilot catchments within the States. Legal reforms establish caps or formal basin closures to establish overall limits to appropriation and to provide legal certainty about the extent, validity and relative priority among competing rights in the consumptive pool. The establishment of caps on water use is, however, incomplete and uneven across the Columbia, and diversion limits have traditionally been based on historical use patterns that already exceed sustainable diversion levels. Although environmental water needs were recognised as beneficial uses as early as the 1940s, and transfers were authorised to convert existing water rights to in-stream purposes, environmental-flow needs have yet to be comprehensively specified or prioritised to guide efficient acquisitions. 
The 1987 Oregon Instream Water Rights Act is a point of departure in the development of markets for environmental flows. The Oregon experience demonstrates an iterative and adaptive process. A diverse set of organisational actors has emerged to implement and manage water transactions for environmental recovery. A series of state-wide or catchment-level programs began to reallocate water rights through temporary and permanent acquisitions and irrigation efficiency savings. Non-profit water trusts, quasi-governmental basin organisations, and government-run water-acquisition programs have become coordinated by nested governance arrangements to achieve basin-wide integration and accountability (Garrick et al. in review). The Columbia Basin Water Transactions Program (CBWTP) formed in 2002 to integrate these nascent efforts at the basin scale by coordinating and administering $\$ 4$ million of annual funding for local partners. Two of 13 sub-basins within CBWTP have achieved their flow targets - the Deschutes of Central Oregon (66.9 GL) and the Lemhi River (15.4 GL) of Idaho-and, by extension, have achieved threshold-level impacts by restoring sufficient habitat to reintroduce salmon species extirpated from the region in the case of the Deschutes (Garrick and Aylward 2010). The environmental-water buyer is the primary source of competition for water along over-allocated tributaries as demand remains low for agricultural transfers and urban growth has been limited until the past decade. As a result, pricing information has been established through two mechanisms in the absence of active water markets for consumptive rights: reverse auctions and case-by-case appraisals using an income cost replacement method that compensates farmers for income forgone.

The implementation experience over the past 15 years offers a group of key lessons about adaptive learning in market-based environmental recovery efforts. The policy reform underpinning market-based recovery has evolved over five decades in response to crises associated with drought, shifting water needs and ecological degradation. It has been necessary to harness these larger drivers to establish institutional changes conducive to the formation of water markets for environmental flows. The adaptive approach has guided the design of transactional tools to address issues of scale and scope. Water transactions initially targeted small tributaries where relatively small net increases in instream flows provide ecological benefits through river connectivity to aid salmon reproduction. Implementation relied on 'seed' leases to establish proof of concept and to assuage irrigator concerns about the impacts of environmental water transactions on agricultural viability. The scope of transactions has expanded to consider other factors limiting salmon recovery. Another lesson is the reliance on cooperation and engagement with local stakeholders to design water-recovery projects with careful attention to irrigator fears, incentives and capital infrastructure needs. Adaptive learning has been the crosscutting theme through proactive monitoring, evaluation and feedback processes. 


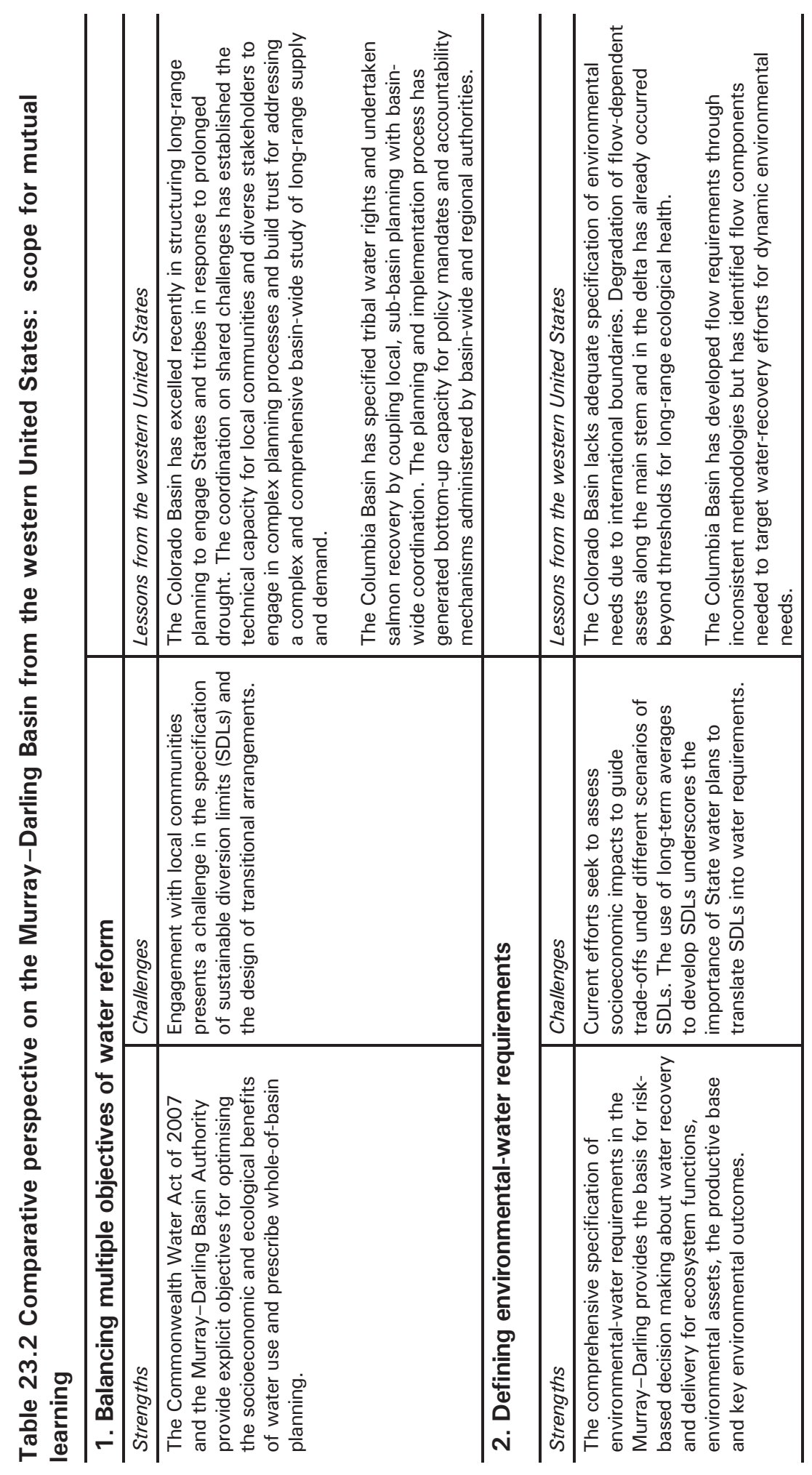




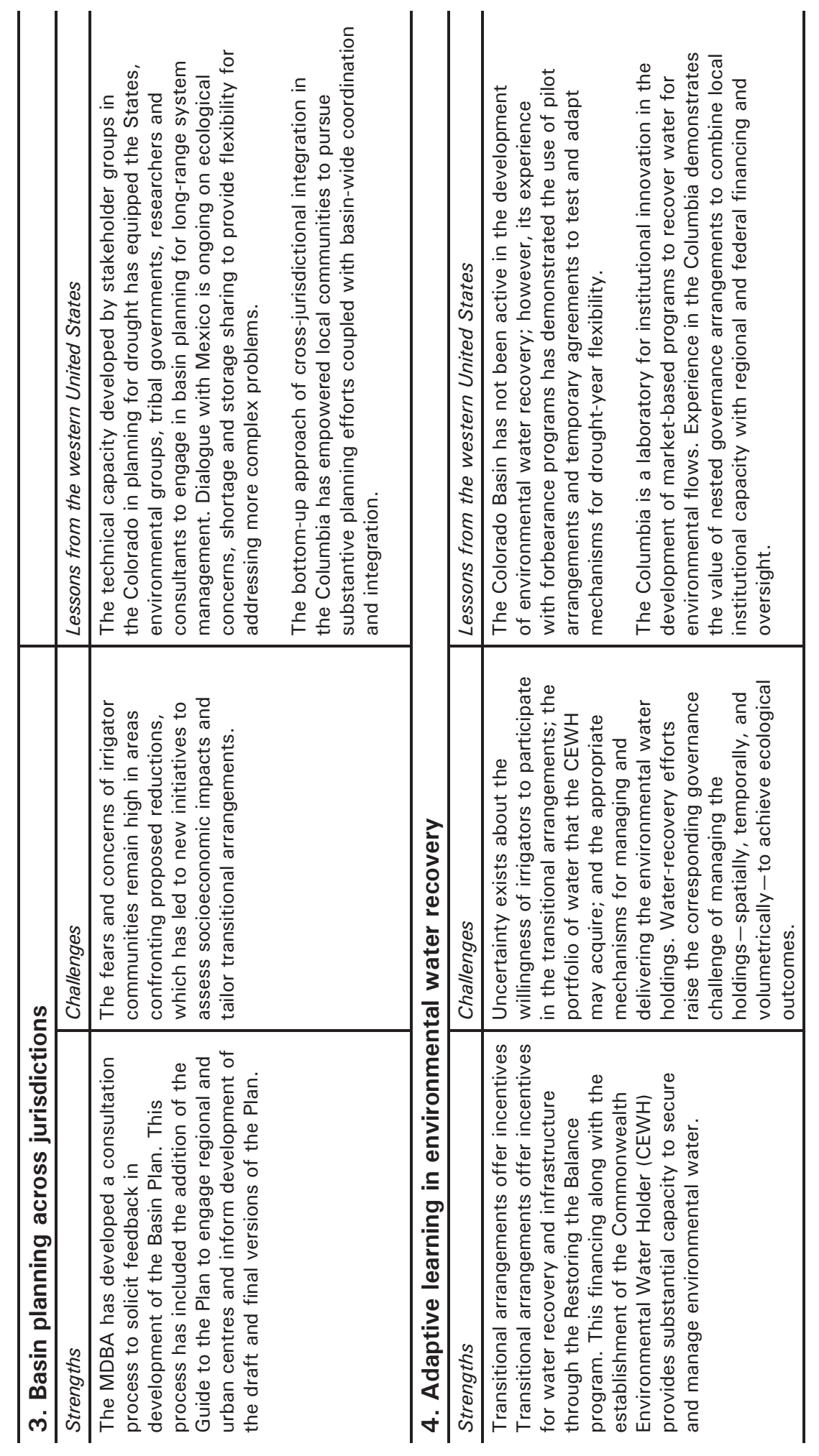




\section{Lessons for the MDB Plan}

This chapter provides a preliminary comparison and seeks to motivate further opportunities for mutual learning between the western United States and Australia as both regions adapt to a water-scarce future. Table 23.2 elaborates key elements of the MDB in terms of the strengths (that is, lessons it imparts to the western United States), challenges, and potential lessons from the western United States.

\section{Conclusions}

What does this preliminary comparison with the western United States offer in the Murray-Darling context? And how could more structured comparison and exchange promote mutual learning about basin governance across multiple jurisdictons? The Colorado and Columbia provide insight on different dimensions of the MDB experience. As the Basin Plan progresses through future development phases and into implementation, the western United States and other international audiences will follow the Murray-Darling as it confronts challenges that international experience suggests are among the hardest to address: coordination of multiple objectives at the national level; comprehensive specification of environmental-water requirements at a whole-of-basin scale with consistent technical criteria to guide operational environmental watering decisions; cross-jurisdictional integration through an independent, basin-wide authority; and transitional arrangements to comply with SDLs. Although the western US reforms are halting and uneven, Australia might find relevant lessons from trial and error in the United States to: engage with and build technical capacity in governmental and non-governmental stakeholders at multiple levels; specify dynamic environmental needs to approximate time- and place-specific flow regimes and to respond to drought-year impacts; promote adaptive learning in market-based environmental recovery through pilot projects, monitoring and evaluation; utilise temporary agreements to build towards permanent protection; and rely on local and State governmental and non-governmental actors to liaise with irrigation communities without losing accountability to basin-scale objectives. The US experience in negotiating tribal water rights is also instructive as Australia seeks to recognise native-title rights to water.

The preliminary comparison developed here underscores the conclusion that the scope for exchanging lessons between the Murray-Darling and the western United States might be broader than previously recognised. Opportunities for mutual learning stem from shared challenges and varying types and levels of 
experience with adaptive river basin management strategies. The development of the Basin Plan provides an impetus for sustained and more systematic comparisons between Australia and the western United States.

\section{Bibliography}

Benson, R. 1996, 'A watershed issue: the role of streamflow protection in northwest river basin management', Environmental Law, vol. 26.

Bonneville Power Administration (BPA) 2010, BPA invests in fish and wildlife, Fact Sheet, Environment, Fish \& Wildlife, Bonneville Power Administration, Portland, Ore., <http://efw.bpa.gov/IntegratedFWP/FACT_SHEET_Invests_ fish_wildlifeFINAL.pdf $>$

Colby, B. and Bark, R. 2010, 'Inter-sectoral water trading as a climate change adaptation strategy', in Q. Grafton and K. Hussey (eds), Water Resources Planning and Management, Cambridge University Press, UK.

Connell, D. and Grafton, R. Q. 2008, 'Planning for water security in the MurrayDarling Basin', Public Policy, vol. 3, no. 1, pp. 67-86.

Garrick, D. and Aylward, B. 2010, Transaction costs and adaptive efficiency in emerging markets for environmental flows: lessons from the Columbia Basin, Economics and Environment Network Symposium, The Australia National University, Canberra.

Garrick, D., Jacobs, K. and Garfin, G. 2008, 'Models, assumptions, and stakeholders: planning for water supply variability in the Colorado River Basin', Journal of American Water Resources Association, vol. 44, pp. 381-98.

Garrick, D., Lane-Miller, C. and McCoy, A. (forthcoming), 'Institutional innovations for governing environmental water in the western US', Economic Papers.

Hardner, J., and Gullison, T. 2007, Independent external evaluation of the Columbia Basin Water Transactions Program (2003-2006), Hardner and Gullison Consulting, Portland.

Jerla, C., Morino, K., Bark, R. and Fulp, T. 2010, 'The role of research and development in drought adaptation on the Colorado River Basin', in Q. Grafton and K. Hussey (eds), Water Resources Planning and Management, Cambridge University Press, UK. 
Langford, J., Briscoe, J. and Porter, M. 2010, 'Creating wealth from water', The Australian, 1 November 2010, <http://www.theaustralian.com.au/creatingwealth-from-our-water/story-fn6nj4ny-1225945844874>

Murray-Darling Basin Authority (MDBA) 2010, Guide to the proposed Basin Plan, Murray-Darling Basin Authority, Canberra.

National Research Council (NRC) 2004, Managing the Columbia River: Instream flows, water withdrawals, and salmon survival, National Academies Press, Washington, DC.

Northwest Power and Conservation Council (NPCC) 2005, 'Deschutes subbasin plan', in Columbia River Basin Fish and Wildlife Program, Portland, Ore.

Pilz, D. (2010), 'Lessons in water policy innovation from the world's driest inhabited continent: using water allocation plans and water markets to manage water scarcity', University of Denver Law Review.

Pulwarty, R. S. and Melis, T. S. 2001, 'Climate extremes and adaptive management on the Colorado River: lessons from the 1997-1998 ENSO event', Journal of Environmental Management, vol. 63, pp. 307-24.

Schoessler, M. A., Blumm, M. C., Swift, B. M., Northwestern School of Law, Northwest Water Law and Policy Project and Western Water Policy Review Advisory Commission 1997, A survey of Columbia River Basin water law institutions and policies, Report to the Western Water Policy Review Advisory Commission.

Tennant, D. L. 1976, 'Instream flow regimens for fish, wildlife, recreation, and related environmental resources', Fisheries, vol. 1, pp. 4, 6-10.

Tharme, R. E. 2003, 'A global perspective on environmental flow assessment: emerging trends in the development and application of environmental flow methodologies for rivers', River Research Applications, vol. 19, pp. 397-441.

US Department of the Interior (USDOI) 2001, 'Record of Decision. Colorado River Interim Surplus Guidelines', Final Environmental Impact Statement, January, Department of the Interior, Washington, DC, <http://www.usbr. gov/lc/region/g4000/surplus/surplus_rod_final.pdf>

US Department of the Interior (USDOI) 2007, Record of Decision. Colorado River Interim Guidelines for Lower Basin Shortages and the Coordinated Operations for Lake Powell and Lake Mead, December, Department of the Interior, Washington, DC, <http://www.usbr.gov/lc/region/programs/strategies/ RecordofDecision.pdf $>$ 
US Department of the Interior (USDOI) 2009, Colorado River Accounting and Water Use Report Arizona, California, and Nevada Calendar Year 2009, Department of the Interior, Washington, DC, <http://www.usbr.gov/lc/ region/g4000/4200Rpts/DecreeRpt/2009/2009.pdf>

Wescoat, J. jr 2005, 'Water policy and cultural exchange: transferring lessons from around the world to the western United States', in In Search of Sustainable Water Management: International lessons for the American west and beyond, Edward Elgar, UK.

White, G. 1957, 'A perspective of river basin development', Law and Contemporary Problems, vol. 22, no. 2, pp. 157-87. 